\title{
EFFECT OF WATER STRESS ON GROWTH AND YIELD OF MUNG BEAN (VIGNA RADIATA L)
}

Ranawake AL*, Dahanayaka N, Amarasingha UGS, Rodrigo WDRJ, Rodrigo UTD

Department of Agricultural Biology, Faculty of Agriculture, University of Ruhuna, Sri Lanka

Accepted: 07 September 2011

\begin{abstract}
Legumes are second only to the Graminae in their importance to humans. Mung bean (Vigna radiata $\mathrm{L}$ ) is one of the most important grain legumes cultivated in Sri Lanka. Drought is a major abiotic stress on Mung bean in the sub-humid, dry and intermediate zones of Sri Lanka. The present study reveals the response of Mung bean for the water stress at three different growth stages; three weeks after planting (3 WAP), six weeks after planting (6 WAP) and eight weeks after planting (8 WAP). A pot experiment was carried out at Faculty of Agriculture, University of Ruhuna, Mapalana, Sri Lanka. Plant height, number of leaves, number of floral buds, dry matter weight of shoot system, number of lateral roots, length of tap root, number of root nodules, and dry matter weight of root system were measured after one week recovery period in 10 day drought stressed plants at three different growth stages and in relevant control plants. Water stress significantly affects on each of the measured parameters at 6 WAP, the flowering and pod filling stage of Mung bean. Only number of leaves was significantly affected when the drought applied at 8 WAP. Further, all the measured parameters other than length of tap root and number of nodules per plant were significantly affected by drought stress at 3 WAP. Number of floral buds and number of pods were not affected by the drought stress at 8 WAP though there is no economical value of these characters as the pod filling efficiency is low in Mung bean under drought stress.
\end{abstract}

Key words: Mung bean, Vigna radiata, water stress

\section{INTRODUCTION}

The major legumes in Asia are chickpea, (Cicer arietinum $\mathrm{L}$ ), pigeonpea (Cajanus cajan L), and Mungbean (Vigna radiata). Mungbean is a warm season crop requiring $90-120$ days of frost free conditions from planting to maturity. Adequate rainfall is required from flowering to late pod filling in order to ensure good yield. Drought problems for Mung beans are worsening with the rapid expansion of waterstressed areas of the world including 3 billion people by 2030 (Postel, 2000). Crop yield of Mung bean is more dependent on an adequate supply of water than on any other single environmental factor (Kramer and Boyer 1997). Among the favorable characters of growing Mung bean short-term growth, nitrogen fixation capability, soil reinforcement and prevention of soil erosion are in top. Mung bean is popular as inter crop, or as mixed crop with cash crops. The rice-wheat cropping system is practiced on 26 million ha in South and East Asia (Abrol et al. 1997; Timsina and Connor 2007). Including Mung bean in the rice rotation system has diversified and strengthened the cropping system, alleviated the disadvantages

\footnotetext{
*Corresponding author : lankaranawake@agbio.ruh.ac.lk
}

of the cereal-cereal cropping system, and improved the productivity of the soil. Mung bean enriches the soil and breaks the soil fatigue caused by cereal-cereal rotations. Including Mung bean in a rice rotation has increased the yield of paddy and the income of farmers in Punjab (Weinberger 2003).

Mung bean which can be grown under low moisture and fertility conditions is one of the important grain legumes in the rain fed farming system in dry and intermediate zones of Sri Lanka . In Sri Lanka the total area under Mung bean in 1980 was around 14,200ha, production was $12,900 \mathrm{t}$ and yield was at $908 \mathrm{~kg} / \mathrm{ha}$. In 1995 , production area rose to $33,200 \mathrm{ha}$, production increased to $26,400 t$, but yield declined to $795 \mathrm{~kg} / \mathrm{ha}$. The improved varieties have encouraged more farmers to plant Mung bean (Weinberger 2003). Presently, Mung bean is successfully cultivated in the districts of Anuradhapura, Polonnaruwa, Vavuniya, Kurunegala, Puttlam, Killinochchi, Mulathiv, Batticaloa and Jaffna. About $80 \%$ of Mung bean crop is cultivated during Maha season as a rain -fed upland crop and the rest is grown in Yala season in paddy fields with supplementary irri- 


\section{RANAWAKE AL ET AL: WATER STRESS EFFECT ON MUNG BEAN}

gation (Department of Agriculture 2001). Mung bean cultivation has to undergo significant drought period in low country dry zone which is the major constrain of growth and pod filling. Effect of drought stress on plant growth, yield and root characters was studied at three different growth stages in the present study.

\section{MATERIALS AND METHODS}

Germinated seeds of Mung bean (Vigna radiata L) variety Harsha were planted after applying recommended basal dressing according to randomized complete block design with 10 replicates for each experiment and 6 plants per each replicate under green house condition. Plants were allowed to grow under normal growth conditions and water cut was done for 10 day period at 3 weeks ( 3 WAP), 6 weeks ( 6 WAP) and 8 weeks after planting ( 8 WAP) in separate sets of experiments while control experiment was maintained under normal growth conditions continuously. Whole experiment was repeated two times. Plants were re-watered after stress period and plant height, number of leaves, number of floral buds, dry matter weight of shoot system, number of lateral roots, number of root nodules, and dry matter weight of root system, were measured after one week recovery period in all three sets of stressed plants and relevant control plants.

To examine the root characters, soil filled planted pots were dipped in a water basin and pots were slanted under the water. After the soils in the pots were loosen, let the soil remove from the pot with water and plants were slowly uprooted.

Another set of replicates were remained for the final yield evaluation. When the stressed plants attained to maturity, number of floral buds, number of pods/plant, and average yield (g)/ plant, were recorded.

Analysis of variance was carried out with the use of Statistical Analysis Systems software (SAS institute 1983) and Duncan's multiple range test was applied to compare the treatment means.

\section{RESULTS AND DISCUSSION}

None of the parameters were significantly affected by the 10 day water stress at 8 WAP other than number of leaves (Fig. 1, table 1). All the measured parameters were significantly affected at 6 WAP while average length of tap root, average number of root nodules and average grain weight per plant were not significantly affected at 3 WAP under 10 day drought stress (Table 1, Fig. 1).

Figure 2 Effect of drought stress on different traits at different growth stages (3 WAP, 6 WAP, 8 WAP) of Mung bean a). average plant height, b). Average number of leaves c). Average number of floral buds d). Average number of pods, e). Average yield (g/plant) f). Average length of tap root, $g$ ) average number of lateral roots, h). Average number of nodules i) Average dry matter weight of shoots j). Average dry matter weight of root

Average yield of the control Mung bean plant was around $4.08 \mathrm{~g} /$ plant while it was $1.5 \mathrm{~g} / \mathrm{plant}$,

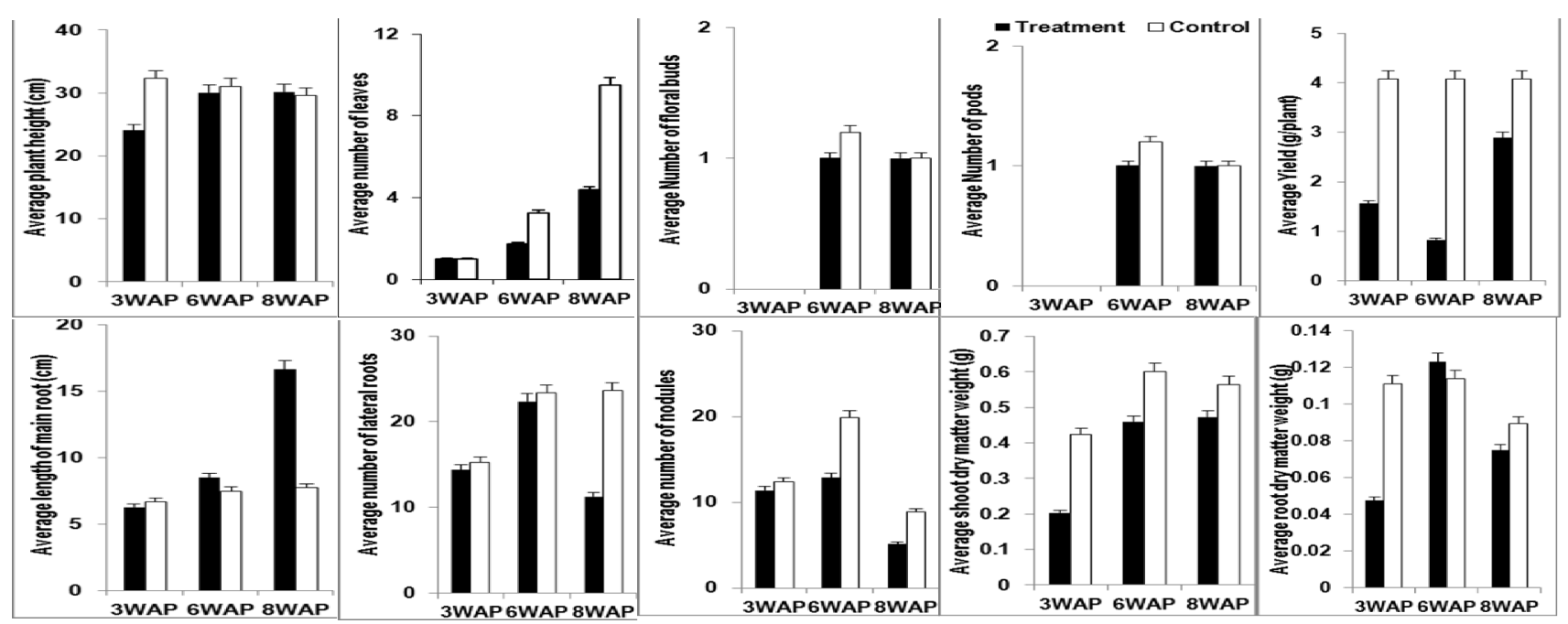


Table 1 Significant level of each character at different growth stages

\begin{tabular}{llll}
\hline & \multicolumn{3}{l}{ P value } \\
\cline { 2 - 4 } Agronomic character & 3 WAP 6 WAP 8 WAP \\
\hline Average plant height & 0.032 & 0 & 0.2582 \\
Average number of leaves & 0 & 0 & 0.0302 \\
Average length of main root & 0.6342 & 0 & 0.4863 \\
Average number of lateral roots & 0.0053 & 0 & 0.4033 \\
Average number of root nodules & 0.4415 & 0 & 0.5263 \\
Average dry matter wgt of shoots & 0.0001 & 0 & 0.50221 \\
Average dry matter wgt of roots & 0.0001 & 0 & 0.5217 \\
Average number of floral buds & & 0 & 0.5233 \\
Average number of pods/plant & & 0 & 0.2447 \\
Average grain weight (g/plant) & 0.0653 & 0 & 0.34 \\
\hline
\end{tabular}

$0.75 \mathrm{~g} /$ plant and $2.9 \mathrm{~g} /$ plant in $3 \mathrm{WAP}, 6 \mathrm{WAP}$ and 8 WAP drought stressed plants consecutively (Fig. 1e). There was a significant difference between control plants and water stressed plants at 6 WAP for all the measured parameters (Table 1). Drought stress at 3 WAP and 6 WAP significantly affects on shoot dry matter weight (Fig. 2i) and root dry matter weight (Fig. 2j). Parallelly, plant height (Fig. 1a) and average length of root system (Fig. 1f) were also significantly reduced at 3 WAP and 6 WAP but not at 8 WAP. Sangakkaran et al. (2000) reported that drought tolerant Mung bean diverted more carbon to roots under moisture stress. When Mung bean is grown under rainfed condition, greater rooting depth helps to acquire stored water from various depths to improve stability in grain yield. Drought stressed plants diverted significantly higher dry matter to roots and stems, while well watered plants diverted to pods and grains (Kumar and Sharma, 2009). It has also been shown that Mung bean genotypes having higher root biomass produced higher pod and seed yield at low level of phosphorous (Boutraa et al.1999).

Water stress also affects crop phenology, leaf area development, number of leaves per plant (Fig. 1b) and finally results in low yield (Abdel and Al-Rawi 2011). Number of leaves per plant is directly related with leaf area/plant and with final dry matter weight of shoots. Prasad et al. (1989) also found higher straw and grain yield of Mung bean with three irrigations as compared to one or no irrigation.

The average number of lateral roots was also significantly reduced at $3 \mathrm{WAP}$ and $6 \mathrm{WAP}$ but not at 8WAP (Fig. 1g). The numbers of roots per plant decrease with decrease in water potential (Dhole VJ and Reddy KS 2010). Reduction in average number of lateral roots directly reduces the root biomass.

Drought induces early flowering though it is not economical due to poor pod setting under drought stress. Thomas et al. (2004) reported that Mung bean plants under water stress attained maturity earlier than the well-watered treatment. Drought tolerance at the reproductive stage is the most important in terms of economic yield. In the present study average number of floral buds and average number of pods/ plant were badly affected at 6 WAP but not at 8 WAP (Fig. 1c and Fig. 1d). The development of reproductive organs, which is under the control of photo-assimilate production and partitioning by the source tissues, is at this stage the most critical (Taiz and Zeiger, 2002; Wahid and Rasul, 2004). Therefore, increased drought at this stage has a pronounced effect on fruit development and yield. Dybing et al. (1986) and Liu et al. (2003) also recorded that in another legume crop soybean; yield was highly affected by drought stress especially when drought overlaps at flowering and early pod setting. The early stage of pod development was characterized by active cell division in the young ovules and rapid pod expansion. The yield loss caused by drought stress was mainly due to an increased rate of floral and pod abortion (Liu et al. 2003).

Nitrogen fixation in crop species is sensitive to environment constrains especially for drought (Arrese et al. 2009). In the present study, number of root nodules was significantly reduced when the drought overlaps Mung bean at 6 WAP (Fig. 1h). There are several factors limiting $\mathrm{N}_{2}$ fixation, such as: high temperature, soil acidity (Hungria \& Vargas, 2000) and water stress (Hungria \& Vargas, 2000; Ramos et al. 2003). Water stress can decrease number and shape of root hairs (Worral \& Roughley, 1976), and when nodules are formed, drought alters nodule structure and weight (Ramos et al. 2003).

\section{CONCLUSION}

Mung bean is sensitive to water stress and water stress significantly affects on root system, shoot bio mass production and final yield. At 3 WAP length of main root and average number of root nodules per plant have not been significantly affected but all the parameters were sig- 


\section{RANAWAKE AL ET AL: WATER STRESS EFFECT ON MUNG BEAN}

nificantly affected by drought stress at 6 WAP. Water stress reduces the development of leaves at any growth stage of Mung bean but significantly reduces final grain yield of the crop according to the growth stage that the drought overlaps the crop. Mung bean must be planted in areas under drought threat so that the dry period would not affect at 6 WAP. At 8 WAP Mung bean is comparatively drought tolerant than other two growth stages; 3 WAP and 6 WAP. However, yield reduction is significant when the drought overlaps the plant at 6 WAP.

\section{ACKNOWLEDGMENT}

First author would like to acknowledge University of Ruhuna for financial support under University research grant scheme.

\section{REFERENCES}

Abdel CG, Thahir and Al-Rawi IM 2011 Response of mungbean (Vigna radiata L., Wilczek) to gibberellic acid (GA3) rates and varying irrigation frequencies International Journal of Biosciences (IJB) 1, (3):85-92.

Abro I P Bronson KF, Duxbury JM and Gupta RK 1997 Long-term soil fertility experiments with rice-wheat rotation in South Asia. In Long-term soil fertility experiments with rice-wheat rotation in South Asia, Rice-Wheat Consortium Paper Series 1, ed. IP Abrol, KF Bronson JM Duxbury and RK Gupta. New Delhi: Rice-Wheat Consortium for the Indo-Gangetic Plains.

Allahmoradi P, Ghobadi M, Taherabadi S and Taherabadi S 2011 Physiological Aspects of Mungbean (Vignaradiata L.) in response to drought stress. International Conference on Food Engineering and Biotechnology, IPCBEE vol.9 IACSIT Press, Singapore

Boutraa T, Iqbal MJ, and Sanders FE 1999 Can we improve the tolerance of Phaseolus vulgaris cultivars to low soil phosphorus by selecting for greater root biomass. J. Experimental Bot. 4:4-39.

Department of Agriculture 2001 Mungbean http:// www.agridept.gov.lk, accessed July $10^{\text {th }}, 2011$.

Dhole VJ And Reddy KS 2010 Gamma rays induced moisture stress tolerant long root mutant in mungbean (Vigna radiata L Wilczek) Electronic Journal of Plant Breeding, 1(5):1299-1305

Dybing CD, Ghiasi H and Paech C 1986 Biochemical characterization of soybean ovary growth from anthesis to abscission of aborting ovaries. Plant Physiol., 81:1069-1074

Hungria M, Vargas MAT 2000Environmental factors affecting $\mathrm{N}_{2}$ fixation in grain legumes in the tropics, with emphasis on Brazil.Field Crop Research,.65:151-164.
Kramer PJ, Boyer JS 1997 Water relations of Plants and Soils, Academic Press, San Diago Arrese I Gonzalez EM Mariano D Landera R Larraiza E Gil-Quintana E 2009 Physiological response of legume nodules to drought, Plant stress, Global Science book, 5 (special Issue):24-31

Kumar A, Sharma KD 2009 Physiological Responses and Dry Matter Partitioning of Summer Mungbean (Vigna radiata L.) Genotypes Subjected to Drought Conditions. J Agron Crop Sci. 95:270-277

Liu F, Andersen MN and Jensen CR 2003. Loss of pod set caused by drought stress is associated withwater status and $\mathrm{ABA}$ content of reproductive structures in soybean. Funct. Plant Biol., 30: 271-280.

Meelu OP and Morris RA 1988 Green manure management in rice-based cropping systems. In Sustainable agriculture: Green manure in rice farming. Laguna, Philippines: International Rice Research Institute.

Postel SL 2000 Entering an era of water scarcity: The challenges ahead. Ecological Applications, 10: 941-948

Ramos MLG, Parsons R, Sprent JI and James EK 2003 Effect of water stress on nitrogen fixation and nodule structure of common bean. Pesquisa Agropecuária Brasileira, 38:339-347.

Sadeghipour O 2009 The influence of water stress on biomass and harvest index in three mungbean cultivars. Asian journal of plant science, vol. 8 (3):245-249.

Sangakkaran UR, Frehner M and Nosberger J 2000 Effect of soil moisture and potassium fertilizer on shoot water potential, photosynthesis and partitioning of carbon in mungbean and cowpea. J Agron Crop Sci. 185:201-207

SAS institute 1983 SAS procedure guide for personal computers. Release 6.03. SAS institute, Langley, North Carolina, USA

Taiz L Zeiger E 2002 Plant Physiology, 3rd ed. Sinauer Associates Inc Publishers Massachusetts

Thomas RMJ, Robertson S, Fukai MB and Peoples S 2004 The effect of timing and severity of water deficit on growth, development, yield accumulation and nitrogen fixation of mung bean. Field Crops Research86: 67-80.

Timsina J and D J Connor 2001. Productivity and management of rice-wheat cropping systems: Issues and challenges. Field Crops Research 69: 93-132.

Wahid A and Rasul E 2000 Photosynthesis in leaf, stem, flower and fruit. In: Pessarakli M (ed) Handbook of Photosynthesis, 2nd ed. CRC Press Florida, pp 479-497

Weinberger K 2003 Impact analysis of Mungbean research in South and Southeast Asia. Final report of GTZ Project. The World Vegetable Center (AVRDC), Shanhua, Taiwan 